\title{
Symptoms of Fusarium graminearum infection in irrigated rice grains
}

\author{
Bruno Tabarelli Scheidt ${ }^{* *}$ (iD) Juliano Berghetti ${ }^{1}$ Eduardo José Zanella ${ }^{2}$ Ricardo Trezzi Casa ${ }^{1}$ \\ Diego Bevilaqua ${ }^{2}$ André Henrique Ludwig²
}

\author{
'Programa de Pós-graduação em Produção Vegetal (PPGPV), Universidade do Estado de Santa Catarina (UDESC), 88.520-000, Lages, SC, \\ Brasil. E-mail: brunotabarelli.s@hotmail.com."Corresponding author. \\ ${ }^{2}$ Universidade do Estado de Santa Catarina (UDESC), Lages, SC, Brasil.
}

ABSTRACT: The fungus Fusarium graminearum was one of the first pathogens described as causing infections in rice; however, in Brazil, there is no description of its occurrence in panicles. The present study aimed to describe the symptoms caused by F. graminearum infection in irrigated rice grains. The experiment was conducted in a greenhouse in duplicate using the irrigated rice cultivar SCS 121CL and hybrid INOV CL at the R4 (flowering) stage. Two isolate of Fusarium graminearium species complex 15A (F. graminearium - 15-ADON) and FmNiv (F. meridionale - Nivalenol), was inoculated onto panicles by spraying with macroconidia and the development of symptoms was monitored until harvest. There was no difference in symptoms among isolates. Light brown spots were observed in the glumes three days after inoculation. These later evolved into brown lesions of irregular shape and size. The glume darkened to purple when the grains were in the filling stage (R6). On maturation, the glume showed dark brown coloration. Severely infected grains were shriveled and brittle.

Key words: Oryzae sativa, Gibberella zeae, infection of grains, symptomology.

Sintomas de infecção por Fusarium graminearum em grãos de arroz irrigado

RESUMO: O fungo Fusarium graminearum foi um dos primeiros patógenos descritos na cultura do arroz, no entanto, no Brasil, não há descrição de sua ocorrência em paniculas. O objetivo desse estudo foi descrever os sintomas ocasionados pela infecção de F. graminearum em grãos de arroz irrigado. O experimento foi conduzido, em casa de vegetação, duas vezes, com a cultivar de arroz irrigado SCS $121 C L$ e o Híbrido INOV CL no estádio R4 (florescimento). Dois isolados de espécies do complexo Fusarium graminearium, 15A (F. graminearium $15 A D O N)$ e FmNiv (F, meridionale - Nivalenol) foram inoculados em paniculas por aspersão de macroconídios, com acompanhamento da evolução dos sintomas até a colheita. Não houve diferença entre os isolados. Pontos de coloração parda foram observados nas glumas três dias após inoculação, evoluindo, posteriormente, para lesões de coloração marrom-claro de tamanho e forma irregular. Houve escurecimento total da gluma com coloração arroxeada quando os grãos encontravam-se no estádio de enchimento de grão (R6). Na maturação de colheita a gluma dos grãos apresentava coloração marrom-escuro. Grãos severamente infectados mostraram-se chochos e quebradiços.

Palavras-chave: Oryzae sativa, Gibberella zeae, infecção de grãos, sintomatologia.

The fungus Fusarium graminearum Schwabe was one of the first pathogens described in rice (Oryza sativa L.) (LEE, 1992). In Brazil, there is no description of the occurrence of this fungus in panicles, either in irrigated or upland rice (KIMATI, 2006; SOSBAI, 2016). However, in a sanitary test conducted on seeds harvested in the Rio Grande do Sul State during the growing seasons of 2008/09, 2009/10, and $2011 / 12$, the following species were found within the $F$. graminearum complex: F. asiaticum (69.6\%), F. graminearum (14.6\%), F. cortaderiae (14.6\%), and $F$. meridionale (1.1\%) (GOMES et al., 2015). The presence of $F$. graminearum in these seeds indicates that fungal infection occurs in the field. According to LEE (1992), rice is more susceptible to infection during the flowering phase and less susceptible in the milky grain stage. This pattern is most likely related to the infection site of the fungus, which, in wheat, is related to the presence of anthers (PANISSON et al., 2002).

Infection by pathogenic fungi, including $F$. graminearum, is associated with dark staining or browning of rice glumes (LEE, 1992; PRABHU et al., 2006; MALAVOLTA et al., 2007); however, there is no available description of symptom development over a period of time in the rice grain. In view of this, it is essential to describe and characterize the timecourse of the symptoms caused by $F$. graminearum infection in the irrigated rice grains.

To begin the characterization, an experiment was conducted during the growing 
seasons of 2015/16 and 2016/17, under greenhouse conditions, at the Centro de Ciências Agroveterinárias of the Universidade do Estado de Santa Catarina in Lages, which is located in the Planalto Catarinense $\left(27^{\circ} 50^{\prime} 35^{\prime \prime} \mathrm{S}\right.$ and $\left.50^{\circ} 29^{\prime} 45^{\prime \prime} \mathrm{W}\right)$ at an altitude of $960 \mathrm{~m}$. The greenhouse was maintained at a daytime temperature of $27^{\circ} \mathrm{C}$ and a nighttime temperature of $21^{\circ} \mathrm{C}$, with a relative air humidity of $75 \%$.

Specimens of the irrigated rice cultivar SCS $121 \mathrm{CL}$ and hybrid INOV CL were grown in plastic vessels with a capacity of $8 \mathrm{~L}$ that contained a substrate of soil, sand, and organic matter in a ratio of $2: 1: 1$. Sowing was carried out on November 23 in both 2015/16 and 2016/17, at a density of ten seeds per vessel. Seedlings were thinned after germination, leaving five young plants to establish in each vessel. Constant irrigation was carried out to maintain soil saturation, simulating field conditions. Additionally, the crop was fertilized to aid development. Preparation of the inoculum was performed in the plant pathology laboratory using a method adapted from REID et al. (1996). Two isolate of $F$. graminearium species complex that had been characterized by its phylogeny and genotype 15A (F. graminearium - 15-ADON $)$ and FmNiv (F. meridionale - Nivalenol) was used (DEL PONTE et al., 2015). Spore production took place in a PSA (potato-sucrose-agar) culture medium on Petri dishes that were incubated in a growth chamber for 10 days at $25^{\circ} \mathrm{C}$ with a photoperiod of $12 \mathrm{~h}$. Sporulation was stimulated using white and black light. Sterile water was added to each dish and the surface of the medium was scraped to create a suspension of spores. Following filtration, dilution, and counting in a Neubauer chamber, the concentration of macroconidia in the suspension was reported to be $2 \times 10^{5} \mathrm{~mL}^{-1}$.

Inoculation of the plants was carried out during the flowering stage (Figure 1a), which is development stage $\mathrm{R} 4$ on the rice phenological scale
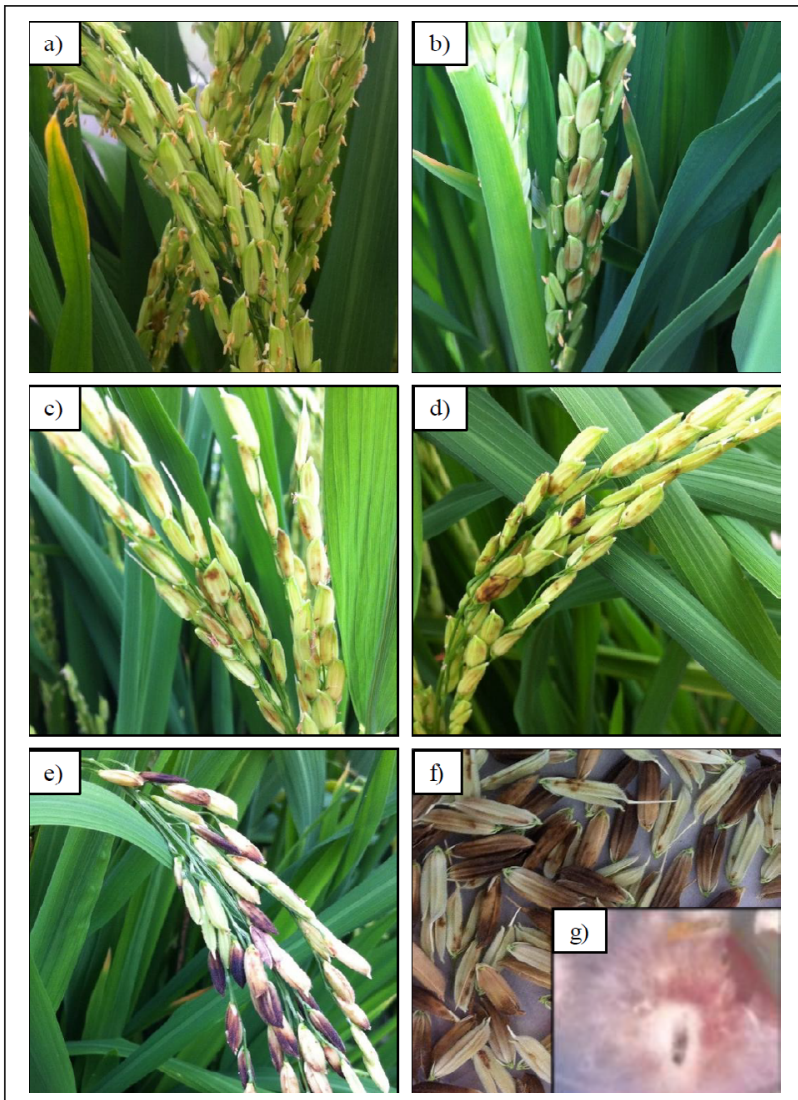

Figure 1 - Development of the symptoms of Fusarium graminearum infection in irrigated rice grains: flowering stage (R4) at inoculation without symptoms (a); first symptoms showing as light brown spots three days after inoculation (b); irregular brown-colored lesions (c) and (d); development of purple-color (e); post-harvest grain symptoms (f); and fungal colony observed by pathological analysis $(\mathrm{g})$. 
(COUNCE et al., 2000). At this point, 40 equally developed panicles were chosen for inoculation. Each panicle was sprinkled with a suspension of the inoculum and covered with a transparent plastic bag for $48 \mathrm{~h}$ to promote a favorable environment for infection. Some panicles were inoculated only with water and incubated in the same manner. Following inoculation, the panicles were monitored daily for the development of pathogenic symptoms. At maturation, the grains were harvested manually and incubated in PSA medium for seven days in a growth chamber at $25^{\circ} \mathrm{C}$ with a $12 \mathrm{~h}$ photoperiod. During this time, plants were assessed to confirm colonization.

There was no difference of the symptoms among the isolates. No symptoms were detected in the rice grains of the control plants. In the inoculated panicles, the symptoms of $F$. graminearum colonization in glumes appeared three days after inoculation. Initially, light brown spots were observed on the glumes (Figure 1b). These later evolved into brown lesions of irregular size and shape (Figure $1 \mathrm{c}$ and $1 \mathrm{~d})$. The complete darkening in color of the purple glume (Figure 1e) was observed when the grains were in the filling stage (R6), which was $\sim 25$ days after inoculation. At harvest, the infected mature grains were dark brown (Figure 1f), and as a function of the relative humidity in the greenhouse, production of mycelium and spore masses was observed in some glumes, resulting in a salmon coloration. Severely infected grains appeared to be shriveled and brittle. In all the symptomatic grains seeded in culture medium, the presence of $F$. graminearum colonies was confirmed (Figure 1g).

\section{ACKNOWLEDGEMENTS}

The reserach was financed in part by the Coordenação de Aperfeiçoamento de Pessoal de Nível Superior (CAPES), Brasil, Finance code 001.DB and AHL had fellowships from CNPq.

\section{DECLARATION OF CONFLICTING INTERESTS}

The authors declare no conflict of interest. The founding sponsors had no role in the design of the study; in the collection, analyses, or interpretation of data; in the writing of the manuscript, and in the decision to publish the results.

\section{AUTHORS' CONTRIBUTIONS}

BTS and RTC designed and designed the experiments BTS, DB, AHL, EJZ performed the experiments. BTS and JB performed the writing and emission of photos in the manuscript. All authors critically reviewed the manuscript and approved the final version.

\section{REFERENCES}

COUNCE, P.A. et al. A uniform, objective and adaptive system for expressing rice development. Crop Science, v.40, n.2, p.436-443, 2000. Available from: <http://crop.scijournals.org/cgi/content/ abstract/40/2/436>. Accessed: Mar. 18, 2018.

DEL PONTE, M.E et al. Regional and field-specific factors affect the composition of Fusarium head blight pathogens in subtropical no-till wheat agroecosystem of Brazil. Phytopathology v.105, p.246-254, 2015. Available from: <https:/apsjournals.apsnet.org/ doi/pdf/10.1094/PHYTO-04-14-0102>. Accessed: Jun. 16, 2018. doi: 10.1094/PHYTO-04-14-0102-R.

GOMES, L.B. et al. Species composition, toxigenic potential and pathogenicity of Fusarium graminearum species complex isolates from southern Brazilian rice. Plant Pathology, v.64, p.980-987. Available from: <https://onlinelibrary.wiley.com/ doi/abs/10.1111/ppa.12332>. Accessed: Jun. 25, 2018. doi: $10.1111 /$ ppa. 12332 .

KIMATI, H. et al. Manual de fitopatologia. 4. ed. São Paulo: Agonômica Ceres, 2005. v.2.

LEE, F.N. Scab. In: WEBSTER, R.K.; GUNNELL, P.S. (Eds.). Compendium of rice diseases. The American Phytopathological Society. APS Press: St. Paul, 1992. p.30-30.

MALAVOLTA, V.M.A. et al. Fungi incidence and damage evaluation on seeds of rice genotypes. Summa Phytopatologica, v.33, p.280-286, 2007. Available from: <http://www.scielo.br/ scielo.php?script $=$ sci_arttext\&pid $=$ S0034737X2014000400009>. Accessed: Jul, 12, 2018.

PANISSON, E. et al. Assessment of air-borne inoculum of Gibberella zeae and the infection of anthers in wheat crops. Fitopatologia Brasileira, v.27, p.489-494, 2002. Available from: $<$ http://www.scielo.br/scielo.php?pid=S010041582002000500009 $\&$ script $=$ sci abstract\&tlng=pt $>$. Accessed: Apr. 14, 2018.

PRABHU, A.S. et al. Doenças e seu controle. In: SANTOS A.B.; STONE, L.F.; VIEIRA, N.R.A. (Eds.). A cultura do arroz no Brasil. 2.ed. Santo Antônio de Goiás: Embrapa Arroz e Feijão, 2006. p.561-590.

REID, L.M.; HAMILTON, R.I. Effects of inoculation position, timing, macroconidial concentration, and irrigation on resistance of maize to Fusarium graminearum infection through kernels. Canadian Journal Plant Pathology v.18, p.279-285, 1996. Available from: <https://doi.org/10.1080/07060669609500625>. Accessed: Jul. 19, 2018. Published online: 29 Dec 2009. doi: $10.1080 / 07060669609500625$.

SOSBAI. Arroz irrigado: Recomendações técnicas da pesquisa para o Sul do Brasil / Sociedade Sul-Brasileira de Arroz Irrigado; XXXI Reunião Técnica da Cultura do Arroz Irrigado. Bento Gonçalves, RS, p.200, 2016. Available from: $<$ http://www.sosbai. com.br/docs/Boletim_RT_2016.pdf $>$ Accessed: Aug. 08, 2018. 